\title{
Reflexivity of Salat and Hahslm as Pre Design by God Into Religion and Science Due to Economics with Covid-19
}

\author{
Roikhan Mochamad Aziz ${ }^{1 *}$ \\ ${ }^{1}$ Universitas Islam Negeri Syarif Hidayatullah Jakarta, Indonesia \\ ${ }^{*}$ Corresponding author.Email: roikhan.ma@uinjkt.ac.id
}

\begin{abstract}
The study was intended to analyze the reflections of worship as the design of the universe by god as the creator of it to be human and the parallel universe is linked to the economic dynamics of the covid pandemic mathematically and hahslm. In interconnection integration, it takes ontology for the basis of theoretical development. Identifying the problem of Islamic meaning in the dichotomy of religious science and science that requires a central theory to bridge the presence of religious science with science. It even required the presence of an ontology of religion as the value of worship to mediate from the dualism of science which was only a single science because of coming from the one god. The meaning of worship as a preliminary design of creation can be reflected in patterns of shadows, mirrors, and humans. The study used a qualitative descriptive approach from the Koran's review literature, hadiths, journals, books, and Internet media. The methodologies used are reflexivity and kaffah thinking with hahslm theory. Studies have shown that the creator's reflectivity from salat to the first design of creation that produced the universe. The simultaneous integration of interconnections would serve to bring religious dualism and knowledge into a comprehensive science through multi-disciplines, interdisciplinary, and transdisciplinary. Symbols of the creator and salat are stored in 19 mathematically in the covid-19 pandemic that also occurs in hahslm or 472319. This pandemic era brought economies into turmoil in Indonesia and global.
\end{abstract}

Keywords: Reflexivity, Salat, Hahslm, Integration

\section{INTRODUCTION}

There are a few discourses in the development of Islam and knowledge, among other things: Islamization, integration, Islam and knowledge, religion and science, multi-disciplines, interdisciplinary, and reflections. Islamization is the first movement in this discipline. The pioneer of the theory of Islamization was motorized by Ismail Faruki. This figure proposes the need to develop Islamic science [1]. Because, in a previous period, Islam already had a superior civilization. Islamic civilization was higher from prophetic times to the industrial revolution. The return of science to Islam was done first by naturalization. After naturalization, which means science is free of value and no longer secular, so it is on Islamization. The approach of Islamization is made by referring to the Koran and the relevant hadiths, and so it and the hadiths are required references to the Islamization approach.

The development of Islamization has been perfected with an approach to integration. Integration figures like
Mulyadhi Kartanegara exclaim that all scientific sources come from god. In the Quran, God mentions on god's side is Islam (QS. Ali Imran [3]:19). Because science comes from God, it is automatically Islam [2]. If Islamic already Islam, there is no need for Islamization. Islamic and scientific dichotomy emerged after the development of western science in the Renaissance of Europe, during the development of the industrial revolution. Science is equated with the emulation that is the development of the kauniyah verse of a cosmic phenomenon [3]. The scientific advance in economics is a quantitative approach using the software as a tool of analysis in its methodology.

The whole science that scientists and academics are creating is searching for a new base as a secure place to get back to the leaps of science. Then came the questions to address the above problems in the form of puzzles [4], the need for a new epistemology that could connect the human desire to reach the top of science with the availability of data and knowledge. 
Then there would be a convergence issue in the question: is Islam capable of explaining the nature of the turbulence in modern science? This will be an opportunity for Islamization to react. The definition begins with the general theory that Islam is a method so that the next Islam will have a specific purpose in a sequence of equations or formulas. Islam, as the key pillar of the religion [5], states in Al-Quran that 'Dyn (system) in the sight of Allah is Islam.

There is also an approach that combines with the various disciplines of multidiscipline. There is also an approach that combines with different disciplines called inter-discipline [6]. Its development has also reflected a reflexive approach that approaches the basic theory of ontology. Reflexivity is a reflection of the blueprint that radiates in existing science and natural phenomena.

The problem of the study of Islam and this knowledge is:

1. It takes ontology from the merging of Islam and knowledge

2. Analyzing Islam and knowledge of the reflections of salat.

The term integration itself is generally understood as blending into a complete or unified unity. 2 Based on this understanding, the integration of science that brings together the religious sciences and the general/secular sciences requires an amalgamation of the two scientific groups so that they become a unity. round and whole. Integration of knowledge is not enough to provide a justification for verses of the Koran (and/or the Prophet's hadith.) in each scientific field and scientific discoveries, give Arabic or Islamic labels to scientific terms, and the like, but there needs to be a paradigm shift based on general scholarship, especially originating from the West, to conform to the basis and repertoire of Islamic scholarship related to metaphysical, religious, and sacred texts. If you look at the golden history of Islamic civilization, it is evident that progress was due to the integrated and holistic understanding of the ulama towards verse qauliyah and verse kauniyah. So that there is no dichotomy between the sciences.

There is a philosophy of integration such as ontology. In Islam, the ideals of science are derived from the Quran and Hadits in the form of universal principles [7]. The broad creation of all science are designed by salat. The introduction of all this ibadah idea is the beginning of the entire life system. Before God had created the universe, the creator set up the design of worship [8]. All creations by God could be reflected as the ibadah.

The new idea may be a scientific method because it has fundamental knowledge based on empirical science. Epistemology is one of the elements of philosophy studies. Epistemology is a branch of philosophy that extensively examines the entire method of receiving knowledge [9]. Epistemology has examined the philosophy of knowledge, which refers to the roots of science, how to acquire knowledge and the truth of thought.

Islam can be seen as a philosophy with a systematic approach, a detailed view, and a Kaffah viewpoint. Then Islam, as a method, is the origin of the idea of incorporation into science and philosophy [10].

The word of Islam has a root word of 3 initial letters and 1 letter which are alphabet 'a' or alif in Arabic, 's' or sin in Arabic, alphabet 'l' or lam, and alphabet 'or mim' in Arabic. There is a word in the Holy Book of the Moslem [11], the Quran, as the primary source of the sense of ontology for Islam, that is, the QS. Ali Imran[3]: verse 19.

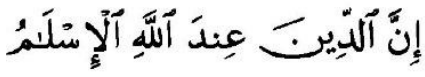

"The system beside Allah is Islam".

It is not enough to research epistemology without explaining its axiology. As a result of Islamic epistemology, a description of axiology must be included [12]. Science of Islam research for axiology describes the important know-how and the gain of experience. A human being does not do something without the incorporation of advantages and disadvantages.

The role of epistemology in Islam that has created axiology in the form of equilibrium for real human life. Start with ontology as Islam for the fundamentals of life, then axiology as Kaffah for science, and then axiology in the form of the application of knowledge as good and bad for balance.

Kaffah Science arises in axiology based on the argument that the entire meaning of basic existence is Islam [13], which is considered to be a framework. This epistemology can be found in the sentence of the Quran Surah Al-Baqarah[2]: verse 208:

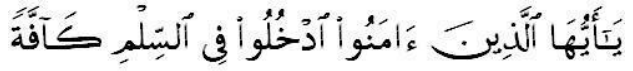

"To religious people enter all of you into Islam by Kâffah".

\subsection{Theoretical Basis}

The birth of the concept of integration was motivated by the dichotomy between the religious sciences and the general sciences. The two of them were separated and seemed to walk in their respective territories. It is also triggered by the separation between the Islamic education system and the modern education system which has a latent impact on Muslims. The developing assumption is 
that "science does not care about religion, so (on the contrary) religion ignores science". This also implies the development of the slogan "science for science", which often creates ethical values in its implementation. Science and religion as if two different entities and separate from each other, have their respective areas, both formal objects - scientific materials, research methods, criteria for truth, the role played by scientists, even to the level of the organizing institution.

Science integration is the amalgamation of science structures. The dichotomic scientific structure should be changed. The structure of science does not separate the branches of religion from the branches of observation, experimentation, and logical reasoning. The integrated scientific building structure is between studies that come from qauliyah verses, Al-Quran, hadiths, and kauniyah verses, the results of observations, experiments, and logical reasoning. The division that is very popular for understanding science is the division into areas of discussion ontology, epistemology, and axiology.

Before the universe was created by God, there was a very fundamental statement for the creation of jin and man. Suit qs. Adz-Dzariyat [51]:56:

"... and not a God created jin and man except for worship"

The creative verses (51.56) form the texts that shape the theory of reflectivity. This verse presents the 3 basic elements made up of god as the creator, the genie, and the man as the creation, and the solat as the purpose of creation. These three elements would be the basis for further theoretical thinking, that in Islam there is a link between the elements at least two separate elements. Derivative of verses of worship (51.56) it is the mathematical theory of triangulation [14]. It is the theory of a recurring number of occurrences. It has the same pattern, so it forms sequences that can be grouped, from complex to simple. There's a sequence of numbers with a pattern of three different Numbers, but sequential over and over again.

\subsection{The Quranic Formula in Islam}

The source for equation $\mathrm{H}=\mathrm{ahq}$ was Quran Surah AlHijr [15]: 87 as numbers 1587 reads: "Walaqad atainaka sab'an minal matsani wal quranal 'azim" which means' And indeed we have given you the repeated 7 and the great Quran' [15]. There is a digit of 4 as a constant or the basic formula of the theory H (HahSLM). And 112 is the amounts of 'Basmalah' which began the surah in the Qur'an. The equation is mathematical: 1587 x $4=112+$ 6236 and numbers 158741126236 are absolute numbers as it creates a spherical multiplication which is the sense of 1587 itself which says 7 that is repeated (112 times) and the great Quran (6236 surah).

\subsection{Theory of Hahslm}

Definition of theory $\mathrm{H}$ according to Aziz [15] is:

1. Narrowly, Theory $\mathrm{H}$ is defined as a theory of three dominant archetypes with a specific context in five dimensions of invariant arrangement.

2. Broadly for the most common use, Theory H can be interpreted as a theory of the basic concept of creating patterns with certain relationships. $\mathrm{H}$ comes from the formula Hahslm, AL-Quran letter Hijr, also stands for Huda or life.

These make up 3 figures of 1 as a symbol of the God, 9 as a symbol of prayer, and 3 as symbols of human Numbers. Three Numbers in the mathematical theory of triangulation to 3.1 .9 or 9.1 .3 , which places the number 1 at the center, between 3 and 9. From Numbers theory, transformations to reflective methods. This theory is a symbolic reflection approach, can come in terms of figures, text shapes, and picture shapes, as well as other shapes [16]. The elements arising are salat, god, and man. The shalat element in this reflexive method is a design, blueprint, or archetype. The element of god becomes the mirror or projector as a creator. And the human element became a symbol of a person standing in front of a mirror, ora symbol of a projection picture, ora symbol of a suit. In a system, according to Islam has at least three elements. Kaffah thinking is a system of three or more interrelated elements. The elements of thinking are embodied in the entities (subject and object), and the entering (worship). The causation of thinking is the three elements are' full variable 'not just the genre or direction [17].

Science of Everything based on the above 3 paradigm of science theory. Second, ontology has made Islam the fundamental concept. Second, Kaffah's epistemology reflected the importance of science. Third, axiology conducted a combination between good and evil.

A new model, the Scientific Method of Islam, can be developed from these three frameworks. This approach can be referred to as the Quran with the words 'Silmi Kâffah,' with the meaning that the word 'silmi' is derived from the letters of sin lam mim8, and sinlammim is the root of Islam.

Sinlammim's scientific method is one of the ways to break the stagnation of modern research to solve some basic problems. This approach attempts to combine science and religion. Sinlammim is necessary to become a counterbalance to resolve the fundamental problem of science [18]. This new paradigm is in line with the growth of the current human understanding that already needs to look for a middle course of problems in established science by providing a new form of spirituality-related theory. From time to time, human 
beings seek a better world and can address the fundamental question of life. One example of how the technique in Sinlammim is very basic can be seen on the human side.

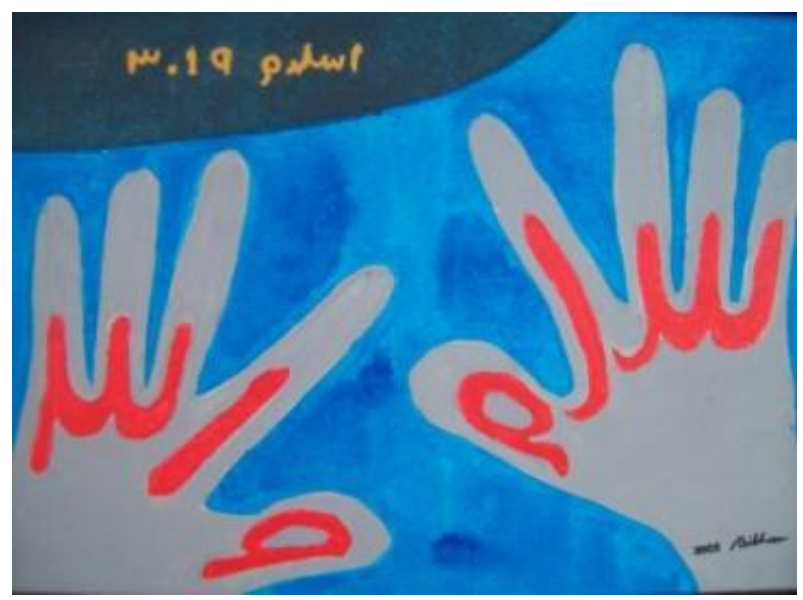

Figure 1. Islam Approach In Hand (Source: Aziz, 2006)

Islamic science can be formed in an academic setting by being combined, with Al-Quran and As-Sunnah, as well as introducing the idea of 4-dimensional elements where the first element is God, the second element is nature, the third element is religious service, and the fourth element is a line.

Integration is more difficult to explain in the nano period in the future. The explanation is that modern science has made substantial progress in certain respects. The potential of the scholar will be more focused and more partial. That will allow a group of scientists to be in the right position and, on the other hand, they are a group of scientists focused on left-wing science. It's going to be more difficult to get a middle scholar again. To satisfy the partial commitment of religion and science, the scholar proposes a new approach that is reflexivity. This would be the potential definition of the reflexivity of Islam and science. Islamization came from scholars with a fiqh approach to then-current growth, as integration is contributed by scholars with a modern approach. In the future, some scholars will establish a principle of reflexivity with an approach to a universal pattern. The distinction between the three theories is Islamization to explain the science that has a relationship with the Quran and the Hadith, Integration to explain science by contrasting the discoveries of classical Islamic scholars with modern scholars, and Reflexivity to explain science by showing the repeated pattern of Islamic treasure and invented science. Representation of Islamization could be pointed out as Malaysia, such as IIUM, for integration could be Indonesia, such as the UIN, which has Islam and Science as a general basic subject, and Reflexivity could be from other parts of the institution.

\subsection{Theory of Integration}

At the beginning of the approach to religion, Islamization was initiated by academics from higher education, such as Malaysia. Indonesia will then be complemented by a new concept of integration.

While Islam or religion centers on the holy book of Koran and hadith, with qauliyah approaches, based on the methods of bayani, burhani, and irfani. The consistency of the approach by western scientists to the physical object and the consistency of the approach by religion in the holy scriptures makes Islamic and religious differentiation increasingly convoluted and increasingly distinct. In the general development of science, this dichotomy adds to the diversity, expansion, and expansion of science in all directions. Add to this the promise of a new science-a combination of religions and sciences from which science once existed, then divided into two religions and science. And there will be multiple disciplines of the broken, so there will be four sciences of one source.

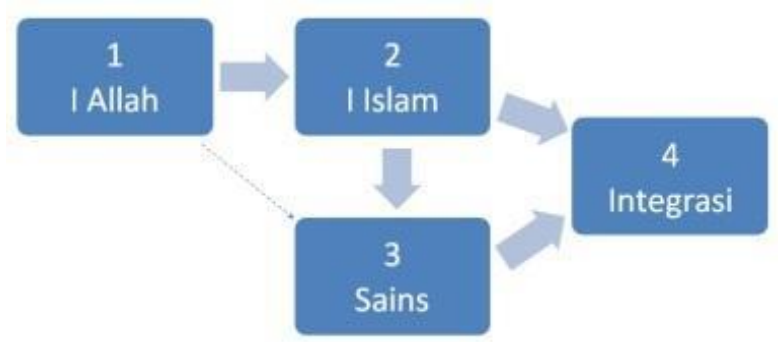

Figure 2. Four Knowledge Into Integration (Source: Analysis, 2020).

The diagram above shows that the source of all knowledge is from god. In the early days of human civilization, god passed down his science to the prophets, it was called the science of god [19]. This knowledge of God is meant to the divinely given knowledge of prophets, including the study of God. This science of god combines with religious science. Then by western scientists, this science from god was relegated to science. And now, with the covid-19 pandemic, researchers are beginning to catalyze the integration of religious science with science. This transition into merging the two approaches is filled with an approach that combines 2 sets of sciences into one system with a theme of Islam and knowledge or religion and science [20]. This approach combines 2 subsystems into one large system. There is still a differentiation presented in one container. 


\section{METHODS}

\subsection{Type of Research}

Type of research is descriptive by analyzing, describing, defining, describing, or explaining the reflexivity regarding integration between Islam and science [21]. This research was conducted with literary studies looking for theoretical references relevant to triangular mathematics, kaffah thinking, and reflexivity.

\subsection{Research Scope}

The scope of the research is about science, Islam, reflexivity, and Mathematics [22] including the study about Islamization and integration.

\subsection{Data Collection Methods}

This research uses secondary data obtained through intermediary media. This data can be obtained through books, notes, existing evidence, or published articles and journals for reference [23].

\subsection{Hahslm Methodology}

This study uses the Hahslm methodology by incorporating the value of worship into data processing. Qualitatively. In the Hahslm methodology, the meaning is that kauniyah is the same as Qauliyah.

The life system that exists in humans, in the environment, and the universe originates from the concept of Islam, in other words, the concept of early creation is Islam. The word Islam has a root word of three letters, namely the letter 's' or sin, the letter 'l' or lam, and the letter ' $\mathrm{m}$ ' or mim. There is a verse that supports the ontological meaning of Islam, namely QS Ali Imran (3) verse 19:

"Verily Din beside Allah is Islam" (Surah Ali Imran [3]: verse 19)

\section{RESULTS AND DISCUSSION}

Islamization and inequality in reflexization have differentiation on its basic philosophy. Islamization and inequality are richer by epistemology. Whereas reflexivity is a concept reflected in the ontology. These reflexes can be seen from the number of letter Numbers, verse Numbers (51.56) which is $5+1+5+6=17$. The number of obligatory prayers is 17 degrees. In this reflexive method of the creation verse the number 19 (one nine). This number 19 is significant in the Koran where the number 19 in the epistle of al-Mudatsir [74]:30. Meaning: over it nineteen. The number of words in verse 1 to verse 29 on this letter of al-Mudatsir, turned out to be 57 words, where $57=3 \times 19$. Of those mathematical calculations come up with a figure of 3.1.9.

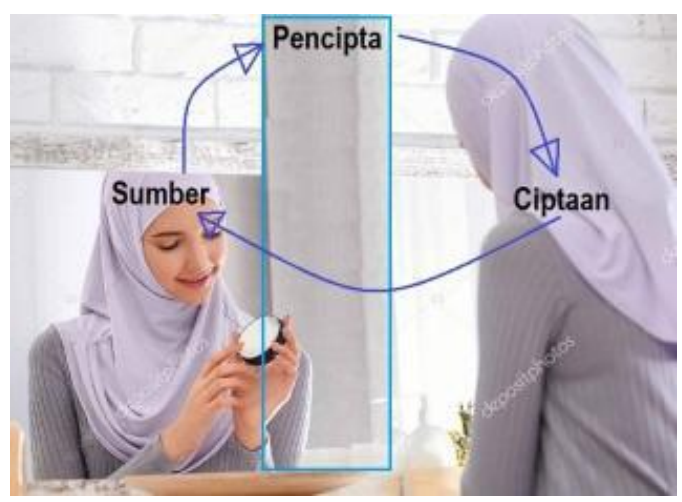

Figure 3. Reflexivity Of Source Creator-Creation (Source: Analysis, 2020).

The reflexivity diagram above consists of the 3 elements that are, the source, the creator, the creation. These three basic elements are converged into reflections of shadow, mirrors, and mirror people. Sources are transformed into shadows, the creator is transformed into mirrors, and creation is incorporated into the mirror. In the process of creation, these three elements are a common thread from sources, creator $=$ god, creation $=$ man, then conversion of salutes $=$ shadow, god $=$ mirror, man $=$ mirror. A system consisting of a 9.1.3 in kaffah's method of thinking suggests that a system that starts from 1 to 3 , then to 9 . When a 9 goes to a 1 , a 9 goes first in the system. It originally meant god created humans for worship [15]. Could be: worship flexibly god forms human.

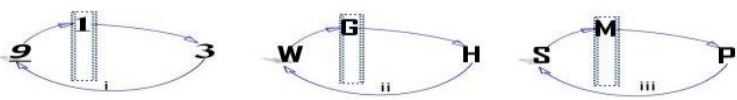

Figure 4. Kaffah Thinking

Source: Analysis, 2020.

Information:

Source: 9 or Worship (W) or Shadow (S)

Creator: 1 or God (G) or Mirror (M)

Creation: 3 or Human $(\mathrm{H})$ or People $(\mathrm{P})$

The kaffah thinking diagram above says that the source of the human reflector is worship, of which is god himself. So, this existing human body is reflexive of worship. The existence of a human body structure is a transformation of the worship symbol. In the kaffah thinking diagram, an easy picture is $\mathrm{s}, \mathrm{m}, \mathrm{p}$. S stands for shadow, $\mathrm{m}$ stands for the mirror, and $\mathrm{p}$ stands for people. The reflection in the mirror is reflected onto the people 
or can be read as well as people have a shadow behind the mirror [24]. No 2 entities are people and mirrors, whereas shadow is an element also called an entering or feedback. In the club, thinking must choose three variables instead of two variables. And 9 or worship is the 3rd variable.

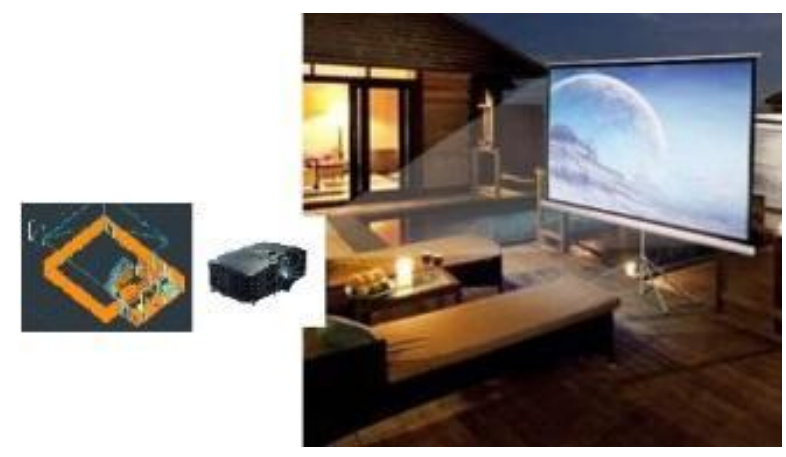

Figure 5. Reflexivity Design of Ibadah (Source: Analysis, 2020).

The reflexivity diagram shows that this third variable exists which is an interpretation of worship. The meaning of the 3rd variable becomes consistent between the existence of the creation verse and the projector function [17]. The existence of a projector is a creator's function that creates a building from the reflexivity and design of an architect's house. So, humans who were created by God came from prayer as the source. Because humans are the reflexivity of worship, the universe and the faculties/study programs will also reflexivity from worship.

From this analysis, faculty/study programs need to interpret the value of worship in the higher education process and also integration. Empirically, the number of human limbs has a similarity in pattern to the number of prayer movements, by the reflexivity interpretation of the verse of creation (51.56). In Sufism, the discourse on the source of worship is by the discussion of Al-Ayan AlTsadisah [25].

Barbour inside his study, When Science Meets Religion: Enemies, Strangers, or Partners? Maps the relationship between Science and Religion into four typologies, namely conflict, independence, dialogue, and integration. According to Barbour, the relationship between science and religion is called "conflict", when science and religion are conflicting and in certain cases even hostile. The relationship between science and religion is called "independence" when science and religion work independently of each other. each other's means, ways, and goals, without disturbing or caring about each other. The relationship between science and religion is called "dialogue" when the relationship between science and religion is mutually open and respectful. Meanwhile, the relationship between science and religion is called "integration", when the relationship between science and religion rests on the belief that the area of study, the design of the approach, and the goals of both are the same and one.

Another thinker, John F. Haught, mapped the relationship between science and religion into four forms of relationship, namely: conflict, contrast, contact, and confirmation. Haught's mapping of the relationship between science and religion is similar to that of Ian G. Barbour but different. While Barbour's map of the relationship between science and religion is typological, Haught's map of the relationship is more of an approach. According to Haught, the Conflict approach is a view which states that basic science and religion cannot be referred to or combined. The Contrast Approach is a view that states that there is no real contradiction between science and religion because they respond to very different problems. The Contrast Approach is a view that states the need for dialogue and interaction between science and religion, especially efforts to find ways how science influences religious and theological understanding. Meanwhile, the Confirmation approach is a view that suggests religion and science strengthen each other. This means that religion can play a role in the development of more meaningful science, and conversely, scientific findings can enrich and renew theological understanding.

Haught views the four approaches to the relationship between science and religion as a kind of "journey". The conflict between science and religion occurs due to the blurring of the boundaries of science and religion because they are considered to be competing in answering the same questions, so people have to choose one of them. Therefore, the first step to take is to draw a clear dividing line to show the contrast between the two. The next step, after the difference between the two fields, is clear, then contact can be made. This step is driven by a strong psychological impulse that somehow the different fields of science need to be coherent. In this position, the theological-implications of scientific theory are drawn into the theological realm, not to "prove" religious doctrine, but simply to interpret scientific findings in terms of religious meaning to understand theology better. The climax is confirmation, namely by trying to root science and its metaphysical assumptions in the basic religious view of reality, which in the three monotheistic religions are rooted in the Being which is called "God". That is why the metaphysical assumption of science called Haught, among other things, is that the temporary realm is a rational "order of existence". According to Haught, without this science, as an intellectual pursuit could not even take its first steps. 
Interestingly, from the two studies conducted by Barbour and Haught, it can be seen that the development of the relationship between science and religion leads to an integrative pattern of relationships, in the terms used by Barbour, or confirmative, in the terms used by Haught. Such developments seem to be in line with the spirit of postmodernism. In line with the epistemological character of postmodernism which wants to embrace various kinds of narratives, from a postmodern perspective, religion is tried to be raised, both as a trend of historical context.

Also, science integration can be understood as an amalgamation of knowledge structures. The structure of science does not separate the branches of religion from the branches of observation, experimentation, and logical reasoning. The integrated scientific building structure is between studies that come from qauliyah verses, AlQuran, hadiths, and kauniyah verses, the results of observations, experiments, and logical reasoning. A very popular division for understanding science is the division into ontology, epistemology, and axiology. Furthermore, according to Mahdi Ghulsyani, the integration of knowledge in interpreting the verses of the Koran about modern science. So that the view that considers the Qur'an as a source of all knowledge is not something new, because we find that many of the great scholars of the previous Muslims held this view. Al-Faruqi also reinforces the assumption that one source of truth means that two or more sources can't occur. This is also proof that scientific integration is by the principles of al tawhîd. To say that the truth is one is therefore not only the same as asserting that God is one, but also the same as asserting that there is no other God except God. For al-Faruqi, acknowledging the Lordship of God and oneness means acknowledging truth and unity without separating between science and religion.

Some of the models offered by experts on science integration are; According to Barbour, the integration models offered are: a) conflict (conflicting); b) independence; c) dialogue; and d) integration. Meanwhile, John F. Haught mapped the relationship between science and religion into four forms of relationship, namely: conflict, contrast, contact, and confirmation. Haught's mapping of the relationship between science and religion is similar to that of Ian G. Barbour but different. While Barbour's map of the relationship between science and religion is typological, Haught's map of the relationship is more of an approach. According to Haught, the Conflict Approach is a view which states that basic science and religion cannot be reconciled or combined. The Contrast Approach is a view that states that there is no real conflict between science and religion because they both respond to very different problems. The Contrast Approach is a view that states the need for dialogue and interaction between science and religion, especially efforts to find ways how science can influence religious and theological understanding. Meanwhile, the Confirmation approach is a view that suggests religion and science strengthen each other. This means that religion can play a role in the development of more meaningful science, and conversely, scientific findings can enrich and renew theological understanding. Another model is also offered by Armahedi Mahzar to classify integration models between science and religion into five models, based on the number of basic concepts that are the main components of the model. If the basic concept is the main component of that model only one is called a monadic model, if two is called a dyadic model, if three is called a triadic model, if four is called tetradic, and if five is called a pentadic model.

The real contribution that will be obtained through the science integration process is that it will be able to produce a conceptual contribution to the conceptual order, contribution to the institutional structure, and contribution to the operational order. In a conceptual order, higher education will be able to produce human resources who fully understand Din Al-Islam kaffah. Meanwhile, in an institutional setting, Islamic universities will be able to compete in various sciences, both religious and scientific studies as a whole without seeing the existing scientific dichotomy. And in an operational setting, tertiary institutions will be able to fully integrate the educational curriculum through the fundamental concepts of kalam, fiqh, tasawuf, and wisdom as compulsory lessons at the first level together; The syllabus and basic books of all integrated faculties include verses from the Al-Qur'an and Hadith that are by these disciplines.

\section{CONCLUSION}

The fundamental of Islam and science with integration is worship. Worship is the source of the pattern of human creation. Humans were created with the value of worship, so the application of true academic and industry values also provides the value of worship. Islamization and integration run simultaneous with reflexivity, with an emphasis on the use of religious value in science.

Reflexivity has 3 elements that are transformed as a shadow, mirror, and human to other entity and intangible elements. Elements of source, creator, and creation can be transformed into salat, God, and universe where the Islamization and Integration can be blended in basic design. The basic design of the universe is salat that is reflected by God as the universe.

God has shown greatness in the simple word of worship can be transformed into multi creations. As an Islamic scholar with the guidance of the Quran and Hadith, the intellectuals must start to develop a new 
theory that is derived by worship. Muslim scholars should try to learn more about the exploration of ibadah from Qawliyah and Kauniyah.

\section{REFERENCES}

[1] T. E. Huff, The rise of early modern science: Islam, China, and the West. Cambridge University Press, 2017.

[2] I. T. B. A. S. O. T. Hour, 19: The Proof of Authenticity: The Secret Knowledge of Al-Qur'anal Azeem, 1st edition. Ibrahim the Beast, a Sign of the Hour, 2014.

[3] M. R. Ibrahim, "The integration of islam and science: Al-Ghazali on causality revisited," 'Ulūm Islāmiyyah J., vol. 197, no. 3584, pp. 1-9, 2015.

[4] A. Ikhwan, "Perguruan Tinggi Islam dan Integrasi Keilmuan Islam," -Tajdid J. Ilmu Tarb., vol. 5, no. 2, pp. 159-187, 2016.

[5] E. Iryani, “al-Qur'an dan Ilmu Pengetahuan,” J. Ilm. Univ. Batanghari Jambi, vol. 17, no. 3, pp. 66-83, 2017.

[6] M. Iqbal, Contemporary Issues in Islam and Science: Volume 2. Routledge, 2017.

[7] K. Khozin and U. Umiarso, "The Philosophy and Methodology of Islam-Science Integration: Unravelling the Transformation of Indonesian Islamic Higher Institutions," Ulumuna, vol. 23, no. 1, Art. no. 1, Jun. 2019, doi: 10.20414/ujis.v23i1.359.

[8] M. Mukharom and H. Aravik, "Kebijakan Nabi Muhammad Saw Menangani Wabah Penyakit Menular dan Implementasinya dalam Konteks Penanggulangan Coronavirus Covid-19," SALAM J. Sos. Dan Budaya Syar-I, vol. 7, no. 3, 2020.

[9] Said NADEEM, "Coronavirus COVID-19: Available Free Literature Provided by Various Companies, Journals and Organizations around the World," J. Ongoing Chem. Res., vol. 5, no. 1, pp. 713, Mar. 2020, doi: 10.5281/zenodo.3722904.

[10] M. Munadi, "Integration of Islam and Science: Study of Two Science Pesantrens (Trensain) in Jombang and Sragen," J. Pendidik. Islam, vol. 5, no. 2, Art. no. 2, Dec. 2016, doi: 10.14421/jpi.2016.52.287-303.

[11] N. Muspiroh, "INTEGRASI NILAI ISLAM DALAM PEMBELAJARAN IPA (Perspektif Pendidikan Islam)," J. Pendidik. Islam, vol. 28, no. 3, Art. no. 3, 2013, doi: 10.15575/jpi.v28i3.560.
[12] M. Nasir, "Reconstructing Distinction Pattern of Science Education Curriculum in Indonesian Islamic Universities: An Integrated Paradigm for Science and Religion," J. Turk. Sci. Educ., vol. 17, no. 1 , Art. no. 1, Mar. 2020.

[13] B. T. A. Nugroho, "Integration of Islamic education with science and technology in Islamic junior high school," MUDARRISA J. Kaji. Pendidik. Islam, vol. 9, no. 1, Art. no. 1, Jun. 2017, doi: 10.18326/mdr.v9i1.1-27.

[14] D. Suharyo, Mukjizat huruf-huruf al-Qur'an: memahami makna al-Qur'an melalui kode dan tinjauan sains. Indonesia: Salima, 2012.

[15] R. M. Aziz, “TEORI H SEBAGAI ILMU WAHYU DAN TURATS DALAM ISLAM," J. Ushuluddin, vol. 24, no. 1, Art. no. 1, Jun. 2016, doi: 10.24014/jush.v24i1.1347.

[16] J. Suprihatiningrum, "Islam - Science Integration Approach in Developing Chemistry Individualized Education Program (IEP) for Students with Disabilities," J. Educ. Learn. EduLearn, vol. 11, no. 4, Art. no. 4, Nov. 2017, doi: 10.11591/edulearn.v11i4.7002.

[17] R. M. Aziz, "Universe Created by Allah Equation of Hahslm 472319 as Big Bang Concept and Eid Pray Symbols," Feb. 2020, pp. 1-4, doi: 10.2991/assehr.k.200220.001.

[18] M. S. Tajuddin and M. K. H. Rofie, "A NEW PARADIGM OF INTEGRATION BETWEEN SCIENCE AND ISLAM: An Epistemological Framework," J. Islam Sci., vol. 1, no. 1, Art. no. 1, 2014, doi: 10.24252/jis.v1i1.2188.

[19] B. Hossain, "Islamization of Monetary Policy of 27 OIC Muslim Countries in Asia: The Successes, The Barriers and The Future Directions," Glob. Rev. Islam. Econ. Bus., vol. 7, no. 2, Art. no. 2, Jan. 2020, doi: 10.14421/grieb.2019.072-04.

[20] M. Huda and M. Mutia, "Mengenal Matematika dalam Perspektif Islam," FOKUS J. Kaji. Keislam. Dan Kemasyarakatan, vol. 2, no. 2, p. 182, Dec. 2017, doi: 10.29240/jf.v2i2.310.

[21] A. R. A. H. Hamid, "Social responsibility of medical journal: a concern for COVID-19 pandemic," Med. J. Indones., vol. 29, no. 1, Art. no. 1, Mar. 2020, doi: 10.13181/mji.ed.204629.

[22] S. BIGLIARDI, "BARBOUR'S TYPOLOGIES AND THE CONTEMPORARY DEBATE ON ISLAM AND SCIENCE," BARBOURS Typol. Contemp. DEBATE ISLAM Sci., vol. 47, no. 3, pp. 501-519, 2012. 
[23] Z. A. Bagir, Science and Religion in a Post Colonial World: Interfaith Perspectives. Australia: ATF Press, 2005.

[24] R. M. Aziz and N. Hasanah, "Reflexivity of Intellectual Capital to Assets in Jakarta Islamic
Index with Hahslm Approach," KnE Soc. Sci., pp. 121-136, Jun. 2018, doi: 10.18502/kss.v3i8.2504.

[25] R. M. Aziz, “GOD EQUATIOPN OF HAHSLM 472319 IN UNIVERSE CREATION,” p. 10, 2019. 